\title{
Court Sight Translation From Text-Linguistic Approach
}

\author{
Chen Yaling \\ Aletheia University, New Taipei City, Taiwan \\ National Taiwan University, Taipei, Taiwan
}

\begin{abstract}
Court interpreting as a type of dialogue or liaison interpreting has recently drawn an increasing level of attention in a variety of disciplines, including legal science, applied linguistics, and translation studies. Amongst discussions relevant to court interpreting, the area of sight translation has yet to be emphasized, despite its importance to the outcome of a trial. In this study I first had observations of court interpreting activities on several occasions. Based on these observations, I then formulated a questionnaire and distributed it to 86 interpreters in two training workshops organized by the Taiwan High Court in 2013. The key findings are as follows: most interpreters consider sight translation to be more difficult than other forms of interpretation in the courtroom; while conducting sight translation many interpreters pause in order to seek clarification or are interrupted; most interpreters would prefer the judge or the prosecutor to orally summarize the text to be sight translated; and, after "negotiation," most practitioners tend to lower the level of formality when dealing with a text written in a formal style. These findings imply that interpreters conducting sight translation render a translation through "negotiation" with other participants of the activity; this negotiation can be seen as an attempt to build a "context" from the perspective of liaison interpreting. This study intends to raise the awareness of court interpreters regarding a number of key issues in sight translation, and the results are hoped to be conducive to the future study of other types of liaison interpreting and interpreting as a whole.
\end{abstract}

Keywords: text linguistic approach, sight translation, court interpreting, liaison interpreting

\section{Introduction}

Court interpreting as one type of dialogue interpreting or liaison interpreting has drawn an increasing level of attention with fertilization of many disciplines including legal science, applied linguistics, and translation studies in the recent years. Combining legal science, applied linguistics, and translation studies, Susan Šarcevic (1997) indicates that legal translations in modern times should be considered as receiver-oriented and communicative. As different jurisdictions have different legal rules for translating their instruments, Šarcevic does not emphasize function or skopos of the target text, but highlights "communicative factors" of the target text. She even criticizes Vermeer's skopos theory or functionalism too simplified. Holding the similar view with Šarcevic's, Hatim and Mason (1997) suggest translation including interpreting activities as a dynamic piece between the text producer and text receiver, with all those textual clues as guiding principles to be monitored closely. In their book they state that,

...many of the concerns of the court interpreters are not shared by the translator of classic poetry... Yet there is a

Chen Yaling, Ph.D. of National Taiwan Normal University, Graduate Institute of Translation \& Interpretation, Assistant Professor of Aletheia University, Department of English, Taiwan; Adjunct Assistant Professor of National Taiwan University. 
common concern which sometimes escapes unnoticed ... the striking uniformity which emerges when translating is looked upon as an act of communication.... (Hatim \& Mason, 1997, p. 1)

The topic of this paper is on sight translation in a court setting. In performing such activities, the sight translator reads a written text and orally delivers the output, which is certainly an act of communication as Šarcevic and Hatim and Mason delineate.

\section{Literature Review}

\section{Sight Translation in Court vs. in Conference}

To begin with, let's address the differences between sight translation and other common types of interpreting activities such as consecutive interpreting and simultaneous interpreting. One thing is common among these activities: All of them have the same end product — an oral re-expression of the source message in the target language. However, the sight translator reads a written text, whereas the interpreter in both simultaneous and consecutive modes listens to a speaker. Though given limited time on analyzing the text, Agrifoglio (2004) considers text analysis paramount in performing sight translation. It is important to have schemata or prior knowledge to help retrieve information according to short-term or long-term memory. In the courtroom where the interpreting is mainly conducted in a liaison mode, interpreters frequently stop on this own to clarify meanings or are interrupted by other participants due to some reasons. Sight translation in the courtroom is therefore very much different from sight translation of conference setting pertaining to this aspect. The followings are three actual examples in the Taiwan courtroom.

(1) Witness Oath (The interpreter was interrupted by the accused about what was "perjury")

Original Text

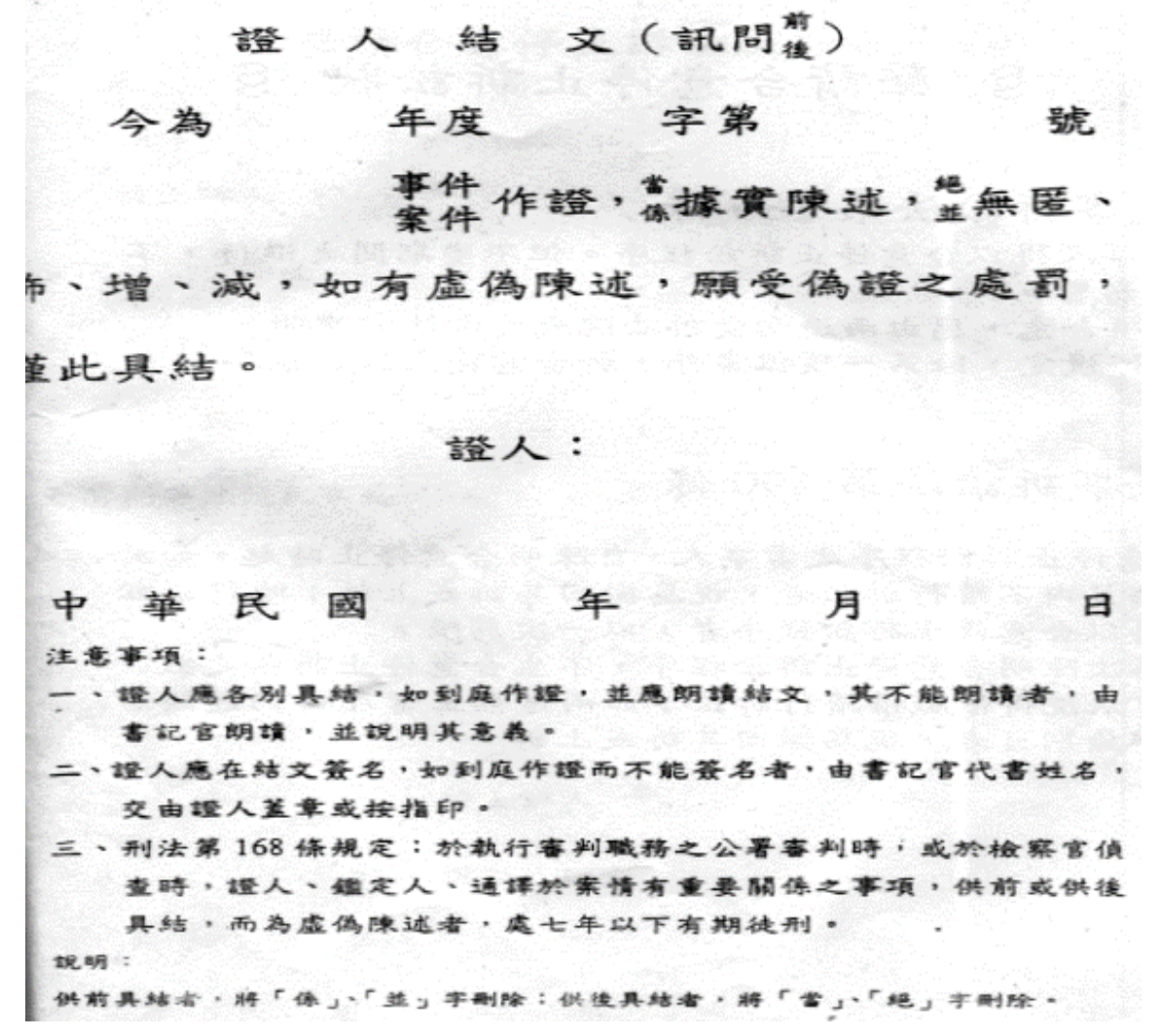




\section{Sight-translated Text}

(Oath Statement) Here I am entrusted by this court and interpreting for case number

in the year . I swear I will interpret accurately, completely, and

impartially, using my best skill and judgment in accordance with the

standards prescribed by law and follow all official guidelines established by

this court for legal interpreting or translating.

Year___Month___ Day

Note: According to Criminal Code Article 168, during public trials, a penalty of

seven years in prison shall be incurred if there is any dishonesty detected in the

oral statement of witnesses, expert witnesses, or interpreters.

(2) Medical Report (the court interpreter stopped to tell the judge there were a few medial terms he didn't know how to interpret.)

\section{Original Text}

解剖檢查發現: 死者男性, 七十歲左右, 蒙古人種。生前未遭受暴力, 死前曾溺水腹部主動脈有硬 化現象, 左, 右冠狀動脈導致右心房與左心室有 $10 \%$ 至 $90 \%$ 的血梗塞, 左心室肥大, 左邊和右邊肺腫, 食物殘餘在細支氣管及左右肺泡, 左右腎臟血管硬化, 另外有脂肪肝和化膿性膽管肝炎等症狀毒性檢查: 發現有咖啡因和乙醇物質。

Sight-translated Text

The autopsy shows the male was around his seventies when he died. He was Mongolian. The body showed no outward signs of violence before death. He drowned before his decease. His abdominal artery showed a sign of sclerosis. His left and right coronary artery gave rise to clogs in vessels of respectively $10 \%$ and $90 \%$ in the right and left heart ventricle. His left heart ventricle suffered from hypertrophy, and his combined lungs had a sign of edema. A residual part of food was left in his terminal respiratory tubes and pulmonary alveolus. He also had intrarenal vascular sclerosis and a fatty liver. He had inflammation of bile duct that caused suppurations.

(3) Charge letter (the interpreter was told to sight translate the charge letter but interrupted by the defendant several times claiming his innocence)

Original Text

被告於民國94年12月4日，在臺北縣中和市（現改制為新北市中和區，下同）一家餐廳舉行公開結 婚儀式並宴請多位賓客, 雖未辦理結婚登記, 惟依當時民法親屬編之規定, 原告仍為被告之合法配偶。 被告明知其係已有配偶之人, 竟基於重婚之犯意, 於 102 年 5 月 20 日與許X前往臺北市中山區戶政事務所 辦理結婚登記（斯時民法親屬編已改採登記婚制度），而重為婚姻。

Sight-translated Text

The Defendant had a public wedding ceremony and a banquet attended by a number of guests. Although the two parties did not officially register as lawful husband and wife, according to the regulations of the ROC Civil Code valid on the day of the wedding ceremony, the Defendant was the lawful spouse of the Plaintiff. The Defendant was fully aware of the aforementioned fact; nonetheless, he registered as the lawful spouse of Hsu X on May 20th, 2013, at the Household Registration Office in the Zhongshan District of Taipei City. The Defendant therefore committed bigamy as defined by the modified regulations of the ROC Civil Code. 
(4) Business Contract

Original Text

根據合同或法律所約定，假若雇主未能依照本合同所約定日期之六個月内支付所聘僱員，X公司有 權在7天前以書面通知雇主進而終止本合同。

Sight-translated Text

According to the law or the clauses from this contract, should the employer fail to pay the employee within 6 (six) months of the date stated in the contract, Company X may notify the employer in writing and terminate the contract 7 days after notifying the employer.

\section{Research Methods}

To find out what is the situation of sight translation in the courtroom. The research of this paper first had observations of interpreting in the courtroom. The researcher got an initial finding that insufficient legal knowledge or legal terms are one of major difficulties interpreter encounters. She then conducted a survey based on results of observations among the practicing interpreters in two workshops organized by the judicial institution, one in May 2013 and another in August 2013, totaling 86 of them island wide. Main findings are as follows: (1) During sight translation, they would stop to clarify meaning or might even be interrupted by participants. (2) As Chinese is not the native language of many south-eastern Asian immigrants, they suggested the judge or the prosecutor give an idea of the facts included in letters of charge or ruling for an easier comprehension. (3) If coming across any legal terms or frozen language, they even lower the level of formality for better understanding.

\section{Results and Discussions}

\section{Results of the Survey}

The reliability of the questionnaire is high (0.753) (see Table 1). Results also show that sight translation is a difficult activity ( $84.8 \%$ scoring 4 or above) in the courtroom regardless of language types (see Table 2 and Figure 1).

Table 1

Reliability

\begin{tabular}{ll}
\hline Cronbach's alpha & No. of items \\
\hline 0.753 & 16 \\
\hline
\end{tabular}

Table 2

Sight Difficulty

\begin{tabular}{llllll}
\hline & & Frequency & Percent & Valid percent & Cumulative percent \\
\hline \multirow{4}{*}{ Valid } & 2 & 4 & 4.7 & 5.1 & 5.1 \\
& 3 & 8 & 9.3 & 10.1 & 15.2 \\
& 4 & 37 & 43.0 & 46.8 & 62.0 \\
& 5 & 30 & 34.9 & 38.0 & 100.0 \\
Missing & Total & 79 & 91.9 & 100.0 & \\
Total & System & 7 & 8.1 & & \\
\hline
\end{tabular}




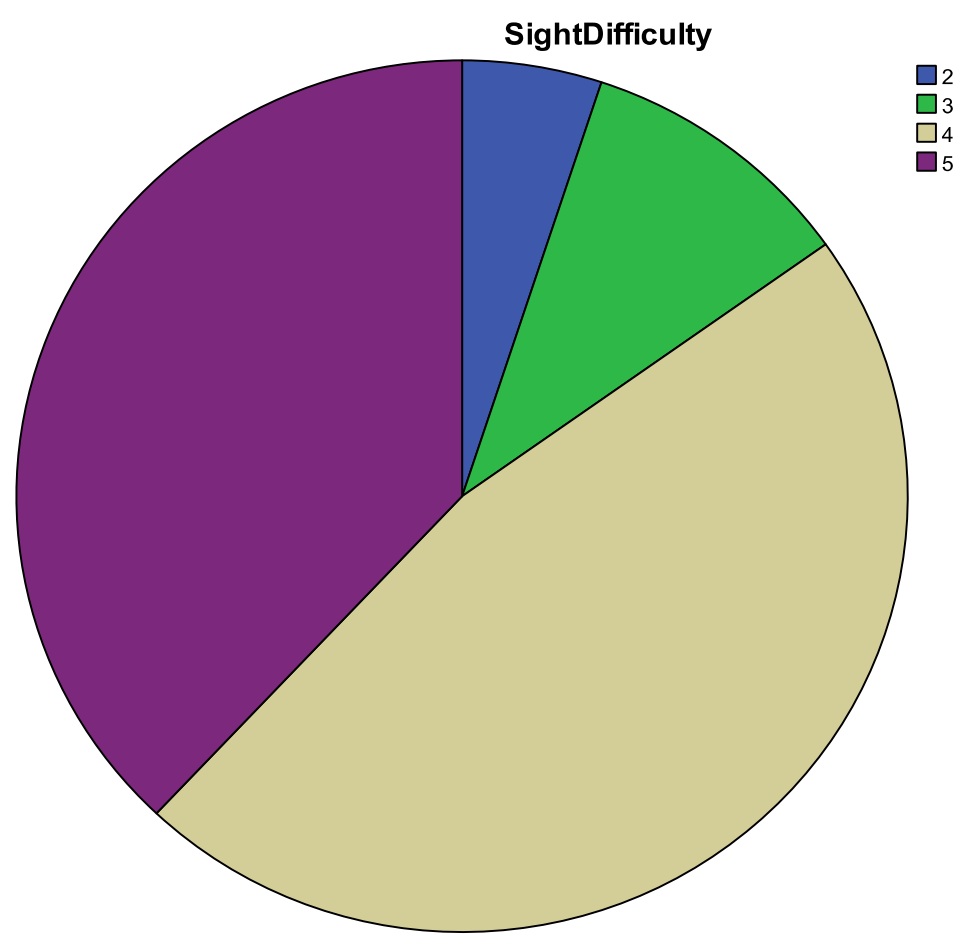

Figure 1. Sight translation difficulty in the courtroom.

Most court interpreters would ask for clarification (72.2\%) (see Table 3 and Figure 2). Some court interpreters would be even interrupted $(48.1 \%$ ) by other participants (see Table 4 and Figure 3). When encountering texts or terms which are hard to understand, a majority of interpreters would lower the register (69.6\%) for communicative purposes (see Table 5 and Figure 4).

Table 3

Court Interpreters Ask for Clarification

\begin{tabular}{llllll}
\hline & & Frequency & Percent & Valid percent & Cumulative percent \\
\hline \multirow{4}{*}{ Valid } & 1 & 3 & 3.5 & 3.8 & 3.8 \\
& 2 & 3 & 3.5 & 3.8 & 7.6 \\
& 3 & 16 & 18.6 & 20.3 & 27.8 \\
& 4 & 41 & 47.7 & 51.9 & 79.7 \\
Missing & 5 & 16 & 18.6 & 20.3 & 100.0 \\
Total & Total & 79 & 91.9 & 100.0 & \\
\hline
\end{tabular}




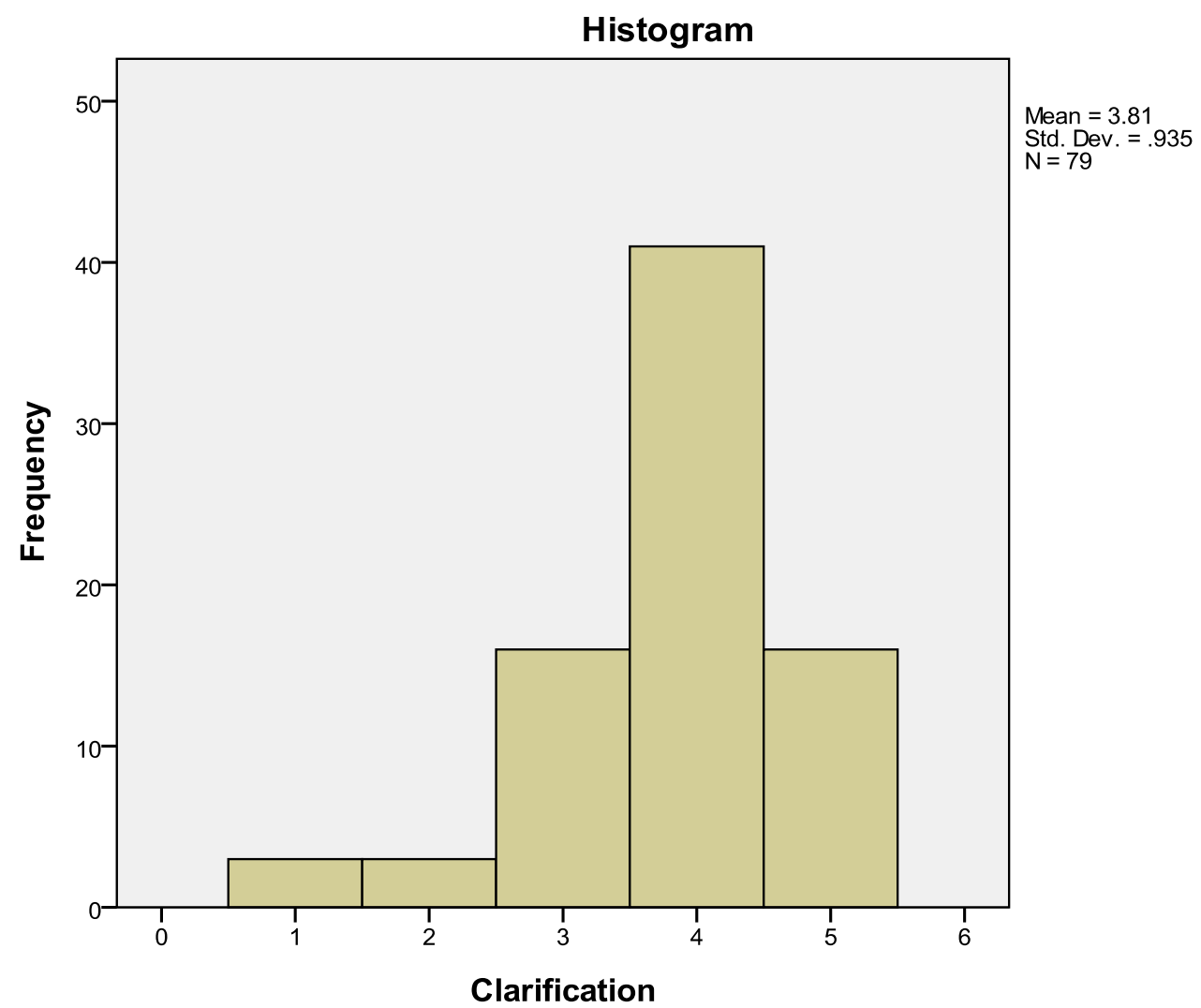

Figure 2. Court interpreters ask for clarification.

Table 4

Court Interpreters Get Interrupted

\begin{tabular}{llllll}
\hline & & Frequency & Percent & Valid percent & Cumulative percent \\
\hline \multirow{4}{*}{ Valid } & 1 & 5 & 5.8 & 6.3 & 6.3 \\
& 2 & 13 & 15.1 & 16.5 & 22.8 \\
& 3 & 23 & 26.7 & 29.1 & 51.9 \\
& 4 & 36 & 41.9 & 45.6 & 97.5 \\
Missing & 5 & 2 & 2.3 & 2.5 & 100.0 \\
Total & Total & 79 & 91.9 & 100.0 & \\
\hline
\end{tabular}




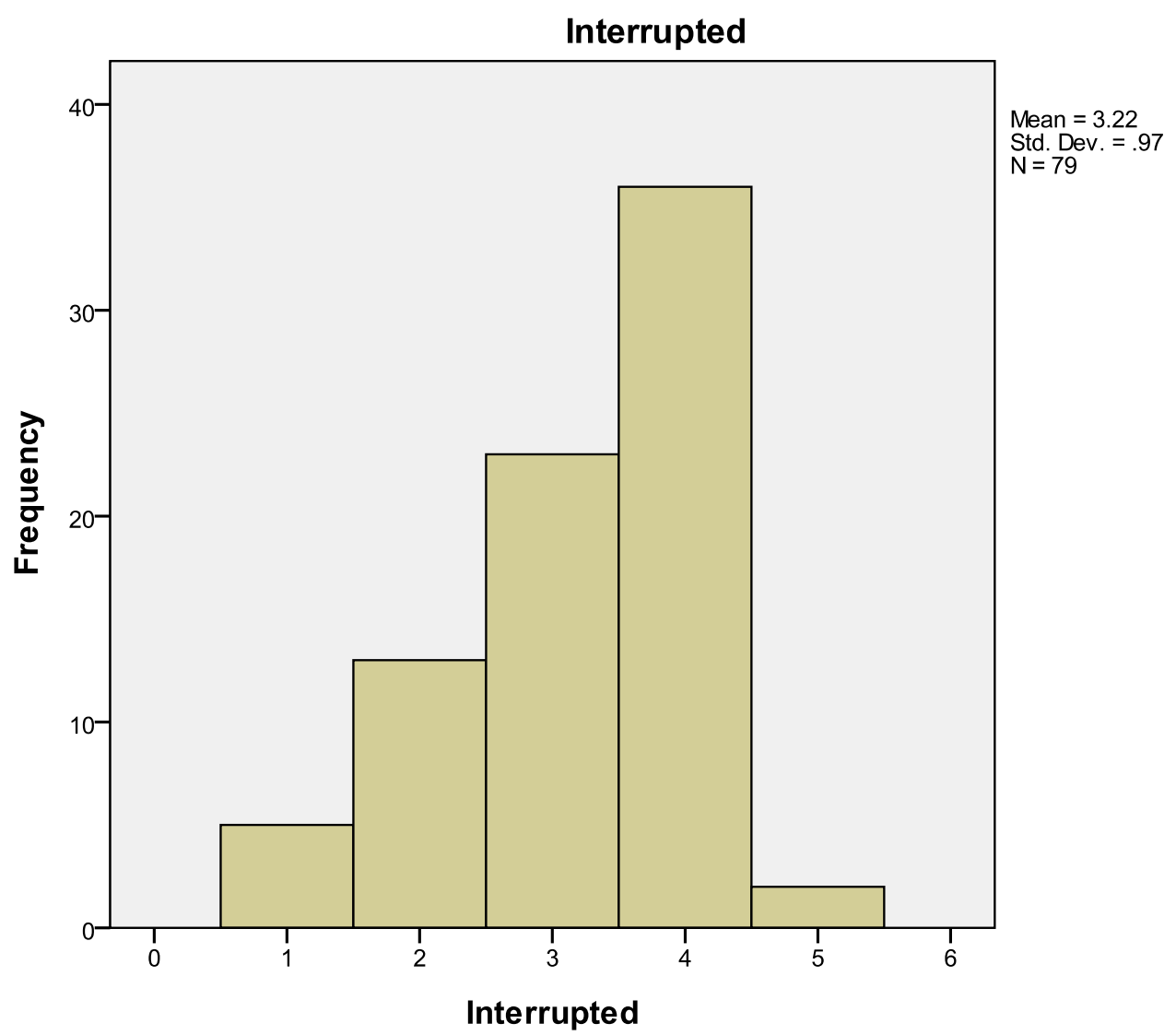

Figure 3. Court interpreters get interrupted.

Table 5

Court Interpreters Lower Register in Delivery

\begin{tabular}{llllll}
\hline & & Frequency & Percent & Valid percent & Cumulative percent \\
\hline \multirow{4}{*}{ Valid } & 1 & 2 & 2.3 & 2.5 & 2.5 \\
& 2 & 10 & 11.6 & 12.7 & 15.2 \\
& 3 & 12 & 14.0 & 15.2 & 30.4 \\
& 4 & 41 & 47.7 & 51.9 & 82.3 \\
& 5 & 14 & 16.3 & 17.7 & 100.0 \\
Missing & Total & 79 & 91.9 & 100.0 & \\
Total & System & 7 & 8.1 & & \\
\hline
\end{tabular}




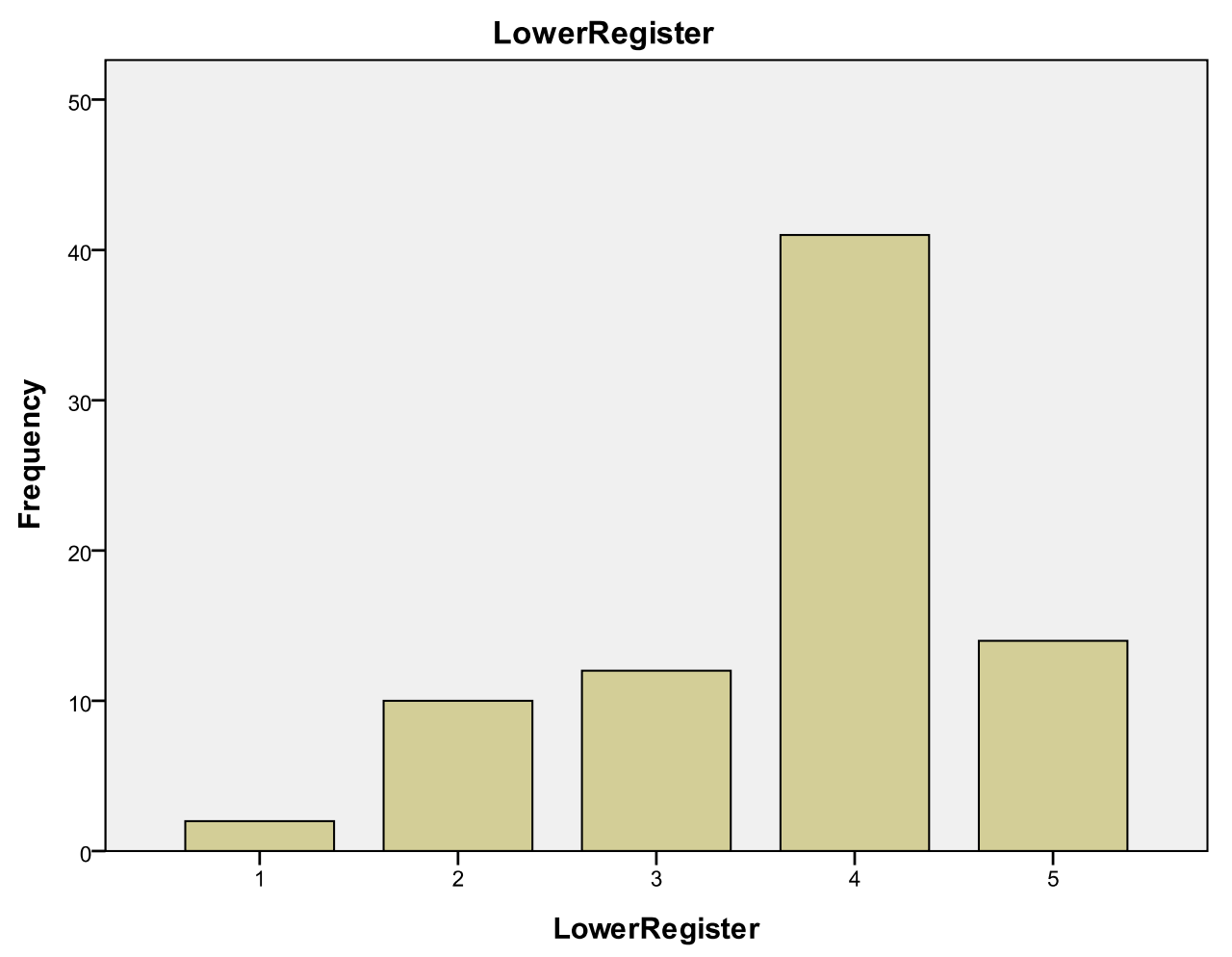

Figure 4. Court interpreters lower their register in delivery.

\section{Hatim and Mason's Text Linguistic Approach}

The above results show court interpreters when performing sight translation actively engage in constructing a "context" of liaison interpreting through negotiation according to the viewpoint of Hatim and Mason (see Figure 5).

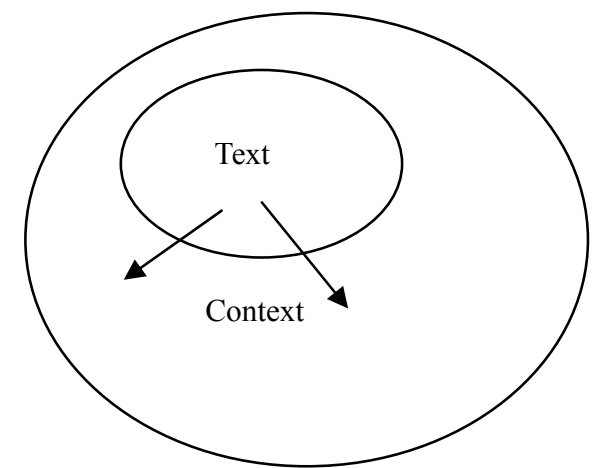

Figure 5. Interpreters constructing context during sight translation. (Source: Compiled by the author)

Moreover, according to Hatim and Mason (1997, p. 51) the "context" includes "register membership", "pragmatics" and "semiotics". Under "Register membership" there are variables of "field", "mode" and "tenor" in dealing with a communicative text. In the courtroom, the "field" court interpreters frequently deal with is those texts of legal discourse, i.e. charge letter or verdicts, noted for their special terminology which is often puzzling to laymen. In the researcher's experience, the court interpreter may sight-translate texts which are represented either in a spoken mode or a written mode requiring reading reflectively to understand. The way we 
choose words and phrases in speaking mode and the way we choose them in writing mode are not the same processes at all. Speaking is done on the fly, while writing is both slow and editable (Chafe \& Danielewicz, 1987, p. 89). To reach a communicative purpose, the interpreter might lower the register for oral delivery when encountering a text that is presented in a written mode.

With reference to factors of pragmatics, take sight translation of the Miranda Rights as an example. At the beginning of each task the interpreter is required to interpret the Miranda Rights to the defendant. The original goes like below:

訊問被告應先告知左列事項:

一、得保持緘默，無須違背自己之意思而為陳述。

二、得選任讋護人, 若你無法負擔, 法院將為你安排一位公設讋護人。

三、得請求調查有利之證據。

We notice the modal verb “de" (得) above at the beginning of each sentence. Two ways of sight-translating these rights, one in a formal register and the other one in a semi-formal register as occurring in dialogical mode, are:

(Formal) You may remain silent in the courtroom. You may appoint an attorney to represent you during the questioning. If you cannot afford an attorney, one will be appointed to you free of charge if you wish...

(Semi-formal) You have the right to remain silent. Anything you say or do may be used against you in a court of law. You have the right to consult an attorney before speaking to the police and to have an attorney present during questioning now or in the future. If you cannot afford an attorney, one will be appointed for you before any questioning, if you wish...

It is obvious that the two interpretations above are proper. However, for pragmatic consideration, some defendants who have low level of literacy or educational background, might feel hard to catch the meaning of legal speech acts stated in Miranda Rights. Sometimes the interpreter is even at a situation to interpret in a very informal way or even make explanation to the defendant to facilitate their understanding.

As to semiotics, it is related to culture-specific requirements during translation or interpretation. Legal discourse being a product of one specific culture, the interpreter is advised to pay attention about how to adapt the legal terms to the receiving culture while achieving equivalent legal function. For example, there are Chameleon-hued words, which tend to have a vague and ambiguous reference, such as "reasonable time", “reasonable compensation”, “reasonable accommodation”. In Chinese we have 相當期限, 正當理由, 適當處 置, 足生損害, 公然侮辱, all indicating a vague and ambiguous meaning. For example, the author once was asked to sight translate the charge letter below (see Figure 6): 


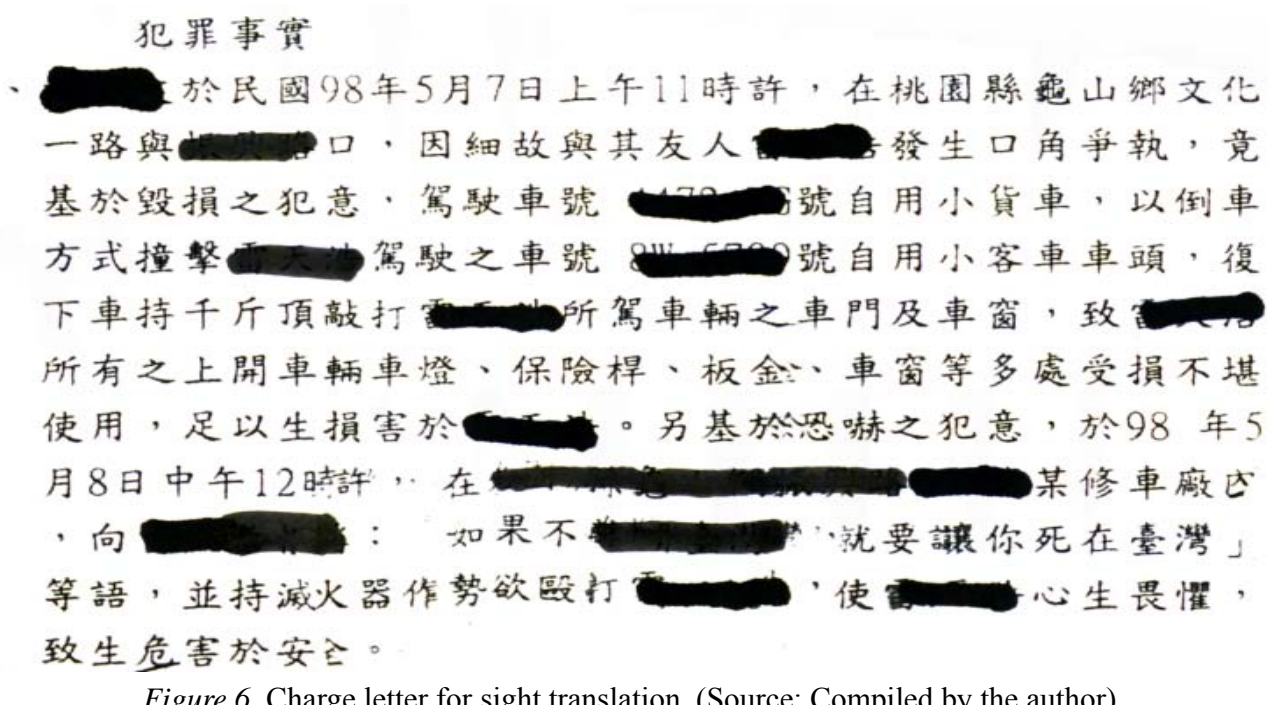

\section{Conclusion}

Hatim and Mason (1997) suggest translation including interpreting activities as a dynamic piece between the text producer and text receiver, with all those textual clues as guiding principles to be monitored closely based on text linguistic approach. As mentioned previously, court interpreting has drawn an increasing level of attention. Amongst discussions relevant to it, sight translation is considered by many interpreting practitioners as a difficult activity ( $84.8 \%$ scoring 4 or above on a Likert scale). Yet, despite a fair level of difficulty, this area has not been emphasized by instructors and researchers. To design a paradigm for this type of interpreting activities, the author therefore suggests an analysis according to Hatim and Mason: The instructor might put an emphasis on the training of such aspects as register membership, pragmatics, and semiotics. When practicing on site, in constructing "context" through negotiation, the interpreter performing sight translation is advised to consider the elements of "context" such as register variables, pragmatics, and semiotics, making adjustment in oral delivery spontaneously. We hope this study may be insightful to analyze the activity of sight translation regardless of interpreting types - conference or judicial or medical types. A revised text-linguistic model for court sight translation based on Hatim and Mason's approach is below (see Figure 7):

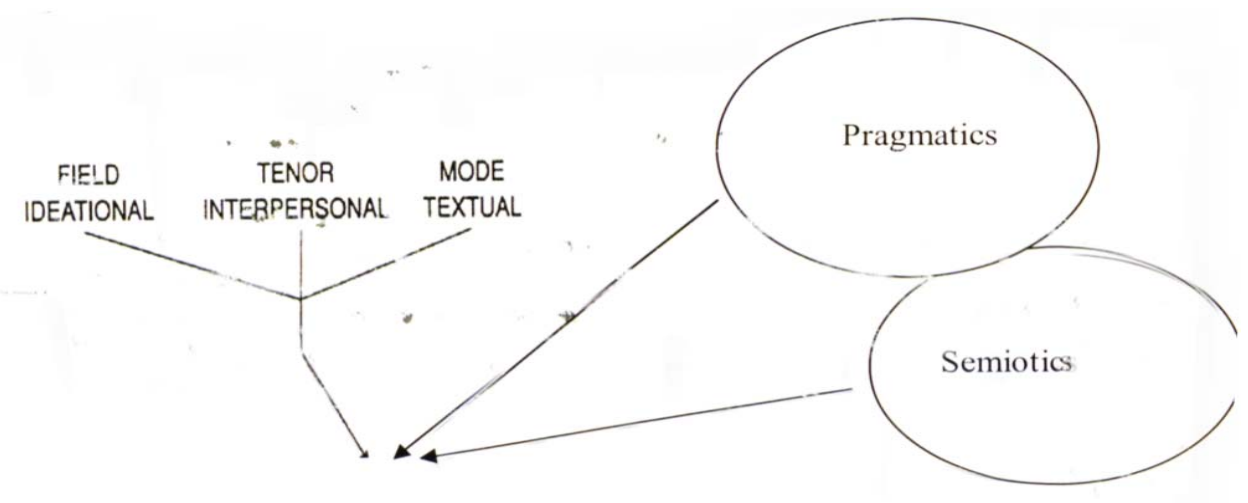

Sight Translation in the Courtroom

Figure 7. Text analysis model for court sight translation. (Source: Compiled by the author) 


\section{References}

Agrifoglio, M. (2004). Sight translation and interpreting. Interpreting, 6(1), 43-67.

Chafe, W., \& Danielewicz, J. (1987). Properties of spoken and written language. In R. Horowitz and S. J. Samuels (Eds.), Comprehending oral and written language (pp. 83-113). London: Academic Press.

Hale, S. (2007). Community interpreting. Hampshire: Palgrave Macmillian.

Hale, S. B. (2008). Working with interpreters effectively in the courtroom (Paper presented at the AIJA conference: "The use of interpreters in court and tribunals", 12-14 March 2008, Freemantle, WA).

Hatim, B., \& Mason, I. (1997). The translator as communicator. London and New York: Routledge.

O'Barr, W. M. (1982). Linguistic evidence. Language, power, and strategy in the courtroom. New York: Academic Press.

Parnell, A., \& Villa, F. (1986). Liaison interpreting as a method of language instruction. Rasssegna Italiana di Linguistica Applicata, 18(1), 25-32.

Šarčević, S. (1997). New approach to legal translation. Cambridge: Kluwer Law International. 


\section{Appendix}

\section{視譯問卷}

各位法庭通譯:

本問卷的目的是想瞭解你在法庭上視譯法律文件的狀況, 所得資料將做為學術研究之用, 不會洩漏任何 個人資料, 請安心作答。你的意見非常寶貴, 請仔細閱讀各部分, 依照個人感受逐題填寫。謝謝你用心 參與。

師大翻譯研究所

博士生：陳雅齡上

一、基本資料：請在 內填寫資料, 或是在口打 $\mathrm{V}$

1. 性別: 口男口女

2. 翻譯語言: 中文和

3. 服務次數(每年) : $\square 0 \sim 5 \quad \square 6 \sim 10 \quad \square 11-15 \quad \square 16-20 \quad \square 21-25$

$\square 26$ 以上

\section{二、問卷内容：請針對以下敘述，圈選適當的數字。}

以下為做視譯 (外文到中文或中文到外文) 時, 你認為會遇到的情況, 5 表十分同意的敘述, 4 表同意的敘述, 3 表 無意見的敘述, 2 表不同意的敘述, 1 表非常不同意的敘述, 以此類推:

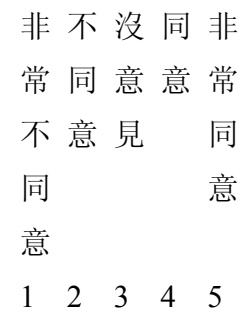

4. 你覺得法庭上翻譯法律相關文件比一般對話口譯困難。

5. 你感到困難的是原文的句型或結構問題。

6. 你感到困難的是專有名詞。

7. 你感到困難的是相關背景知識。

8. 你感到困難的是字彙不足。

9. 你感到困難的是專業術語。

10.你感到困難的是句與句間如何連貫。

11.你感到困難的是文化相關概念。

12.你感到困難的是字詞搭配。

13.過程中我會詢問法官檢察官律師其中法律或相關 術語的涵意。

14. 過程中當事人或其他人會針對你所翻譯, 提問題而 打斷你。 
15. 法律文體和對話文體不同，法庭上你會傾向用較淺顯 的方式翻譯相關文件。(是則跳第17題)

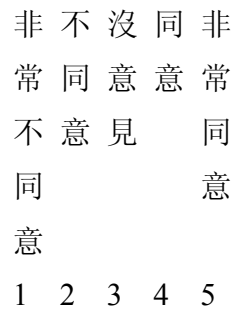

16. 法律文體通常較為正式刻版, 法庭上你會傾向盡量 保留這種性質以作視譯。

17. 你認為事先對文本有初步的概念 (如先收到起訴書) 可使視譯較順手。

18. 你認為先聽講者解釋文稿 (如大致說明起訴書內容), 同時看文本，比較容易做視譯。

19. 你會想要增加法律翻譯的知識, 以利在法庭上視譯 相關文件。

20. 其他的視譯困難:

謝謝填寫！ 